\title{
Ranking Method in Group Decision Support to Determine the Regional Prioritized Areas and Leading Sectors using Garrett Score
}

\author{
Heru Ismanto ${ }^{1}$ \\ Department of Computer Science \\ and Electronics, Faculty of \\ Mathematics and Natural Science. \\ Department of Informatics \\ Engineering, Faculty of Engineering, \\ Musamus University, Merauke, \\ Indonesia
}

\author{
Suharto $^{2}$, Azhari $^{3}$ \\ Department of Computer Science \\ and Electronics, Faculty of \\ Mathematics and Natural Science, \\ Universitas Gadjah Mada, \\ Yogyakarta, \\ Indonesia
}

\author{
Lincolin Arsyad ${ }^{4}$ \\ Department of Economics, Faculty \\ of Economics and Business, \\ Universitas Gadjah Mada, \\ Yogyakarta, Indonesia
}

\begin{abstract}
The main objective of regional development is to achieve equal development in different regions. However, the long duration and complexity of the process may result in the unequal development of some regions. In order to achieve a fair development process for each region, a standard approach must be developed to select a suitable priority area that can support other underdeveloped regions that require attention. One of the approaches taken is to determine the prioritized areas and the leading sectors in the region where the region is expected to be a support for other regions that still need attention and handling on development priorities. This research was conducted to provide a new alternative in the process of determining the prioritized areas, not only by observing the development data, but also involving decision-making components consisting of government and community (including non-governmental organizations and academicians). This study used group decision support approach with the Garrett ranking technique. The results of the research on the determination of the prioritized areas using Garret Score showed that there are 5 of 29 Regencies/Municipalities in Papua Province that can be used as prioritized areas, namely Jayapura Regency, Jayapura Municipality, Mimika, Merauke and Nabire. Then, there are three leading sectors for development, namely agricultural, mining and Industrial and Processing sectors. The test of ranking results was conducted by calculating the Spearman's correlation coefficient of the Garrett ranking results and obtained a coefficient of 0.807 which means that the ranking results are very strong.
\end{abstract}

Keywords-Priority area; leading sector; garrett; decision group support; spearman correlation

\section{INTRODUCTION}

The main objective of regional development is to achieve an equal development that improves the standard of living in different regions. However, the long and complex process involved in regional development makes it difficult to achieve equal development. One of the factors responsible for the difficulty in achieving regional development goals is unequal development in different regions (particularly regions with different economic, cultural and geographic conditions).
Unequal development can be reduced by selecting a priority area and leading sector that will serve as a support for the development of surrounding areas that are still largely underdeveloped [1]. The priority area is an area that is considered to be developed and well-established with human resources, nature and an adequate regional growth center. The area must also have better infrastructure compared to surrounding areas [2].

There are different approaches that can be used to identify a suitable priority area. However, the standard method of regional analysis used to identify priority areas is the shiftshare approach [3], [4]. In order to determine the priority area using this approach, the achievement data from each region is analyzed and the shift-share coefficient value is calculated. However, the use of this approach in the selection of a priority area and leading sector often produces results that do not match the actual facts on the field. There are many instances in which the regions report good development achievements, even though the facts on the field are different.

Therefore, there is a need to develop an approach that does not rely solely on development and achievement data for the selection of a priority area. As a result, the most prominent area that will be chosen. This study developed a group decision support model for the selection of priority areas. This model combines the results of the selection of priority areas based on the development achievement data (shift-share) and a subjective assessment of decision makers that are familiar with the actual conditions on the field. These decision makers worked together to give a valid and reliable assessment of the actual conditions on the field. The most suitable priority area was then chosen in the selection stage, using the Garrett method of ranking. The decision makers that participated in this study include experts (in the field of government and academics) and the general public, including nongovernmental organizations. The decision makers were people who really understand the conditions and facts in their respective regions. Thus, the group decision support model is more complex because it involves diverse assessors. 
The Garrett technique is often applied in alternative ranking using simple steps. Some studies have used this technique to carry out research such as identification of the damage caused by natural factors on betel leaf products [5], identification of the effects of work stress on factory workers [6], [7], employee talent management [8], identification of constraints in cattle crossing processes [9], analysis of constraints to the cultivation of agricultural products [10], [11], analysis of the efficiency of resources used in the field of banana cultivation [12], factor analysis of passengers in determining the choice of travel using railroad facilities [13], analysis of clinical control constraints [14], document ranking for information retrieval [15], ranking of candidate synonyms in the biomedical field on the concept of text mining [16].

This research is divided into seven sections: the first section is the introduction, the second to the fourth section is the literature review, the fifth section is the stage of research, the sixth section presents the results and discussion while the last section present the conclusions generated from this research.

\section{PRIORITY AREA}

The priority area is an area that has many advantages over other regions. The priority area supports development activities in areas that require special treatment [2]. The determination of the priority area begins with the collection of data related to policies implemented in the region. This data is then used to determine the priority area. The next stage is the analysis of the priority areas in a particular area, region or province. The priority area may be located in more than one region in a province.The final stage is the review of legislation. At this stage, the results generated from the analysis of the priority area are integrated with existing regulatory reviews about the area. In addition, the role of local institutions, the conditions of regional institutions were also examined for the purpose of this study.

\section{LEADING SECTOR}

Regional development policies are basically government decisions and interventions, both nationally and regionally to support the overall regional development process. This analysis is very important in order to accelerate regional economic growth, increase the supply of employment and reduce poverty in underdeveloped regions and Border areas. All of this is needed to be able to improve the regional and regional development processes to improve the welfare of local communities.

Efforts to achieve the objectives of regional economic development, the main policy that needs to be done is to make every effort possible so that regional development priorities are in accordance with the potential of the regions. This is related to the development potential of each region that varies greatly, so each region must determine the dominant economic sector [17].

\section{GROUP DECISION SUPPORT}

Group decision support is fast becoming an important in the determination of strategic plans related to the development of specific alternatives. Group decision support can be used to avoid personal conflicts of interest that arise from the decision making process of individuals [18]. The basic concept of group decision support is concerned with fine-tuning the decision making process in the organizational environment by prioritizing the contribution of appointed experts [19].

The concept of group decision support has been used for various purposes such as the needs of human resource management planning [20], management and endurance of emergency conditions in coastal areas [21], also including an applications in the economic field [22].

\section{GARRETT METHOD}

Garrett method is often used to complete the ranking of an alternative based on the ratings of respondents that are converted into certain ranks [23]. This ranking is done by determining the most significant factor from the respondent's answer. The ranking of alternatives using Garrett method is done by calculating the respondent's data as a factor of the percentage position value using the following equation:

Percent Position $(P P)=\frac{100\left(R_{i j}-0.5\right)}{N_{j}}$

Where, $R$ ij is the value of the $\mathrm{i}$ variable given by the respondents to $\mathrm{j}$, while $N j$ is the number of variables assessed by as many as $j$ respondents. The results of the percentage position are then converted into Garrett Values using the Garrett ranking conversion table. The value of $R$ ij is then multiplied by the Garrett Value to determine the Total Garrett Score. The average Garrett Score is then calculated by dividing the Total Garrett Score by the amount of alternatives. The alternative ranking is done based on the highest average value.

\section{RESEARCH METHODOLOGY}

This research began with the collection of the results of the assessment of three elements of decision makers on 29 Regencies / Cities in the Papua Province. The three elements came from the government, the general public including nongovernmental organizations and experts in academics. The three elements were asked to provide subjective assessments. These assessments were based on actual experiences in the field related to the district / city that is a suitable priority area and leading sector in the Papua Province. The assessment was conducted by distributing online questionnaires. The questionnaire had an answer scale of 1 to 4 , which showed the level of achievement and development of an area according to the Klassen typology.

The four scales used in this study include the following, Scale 1: The region is advanced and growing rapidly, HIGH PRIORITY. Scale 2: Developed but depressed region, MEDIUM PRIORITY. Scale 3: Region has advanced potential, MEDIUM PRIORITY. Scale 4: The area is relatively lagging, LOW PRIORITY.

Then, the assessment of the regional leading sector was conducted by choosing an answer on a scale of 1 to 9 consists of nine development sectors. The nine sectors are S1=Agriculture, S2=Mining, S3=Processing Industry, S4=Electricity, Gas and Water utility, S5=Construction, 
S6=Trade, Hotels and Restaurants, S7=Transportation and Communication, S8=Financial, Rental and Business Services, $\mathrm{S} 9=$ Services. The results of the questionnaires were then analyzed in a decision support model scheme in which Garrett technique was used as analysis tool.

The analysis carried out using the Garrett technique was intended to rank the areas that are eligible to be used as a prioritized area according to the assessment of the three elements that have been determined and to determine the rank of the 9 regional leading sectors of the region. The results of the ranking of prioritized areas and regional leading sectors were then tested for the correlation using Spearman Correlation.

\section{RESULTS AND DISCUSSION}

Based on the results of questionnaires, there were fiftythree respondents consisting of three elements of decision makers (government, community (including nongovernmental organizations) and academicians). Each assessor was asked to assess the 29 regencies/municipalities in Papua Province which are feasible to be the prioritized areas and regional leading sectors. Subjective assessment at this stage was very possible. The results obtained from the questionnaires are shown in Table 1 and Table 2.

The next stage was to calculate the percentage of the position of each assessment scale which is the level of feasibility of an area to be a prioritized area and the leading sector of the region.
TABLE I. THE RESUlTS OF THE ASSESSMENT OF DECISION MAKERS

\begin{tabular}{|l|l|l|l|l|l|}
\hline \multirow{2}{*}{ No. } & \multirow{2}{*}{ Territory } & \multicolumn{4}{|l|}{ Priority Level } \\
\cline { 3 - 6 } & & $\mathbf{1}$ & $\mathbf{2}$ & $\mathbf{3}$ & $\mathbf{4}$ \\
\hline 1 & Asmat & 3 & 10 & 29 & 11 \\
\hline 2 & Biak & 9 & 17 & 27 & 0 \\
\hline 3 & Boven Digul & 14 & 6 & 30 & 3 \\
\hline 4 & Deiyai & 1 & 9 & 24 & 19 \\
\hline 5 & Dogiyai & 1 & 14 & 23 & 15 \\
\hline 6 & Intan Jaya & 3 & 19 & 18 & 13 \\
\hline 7 & Kab Jayapura & 37 & 15 & 1 & 0 \\
\hline 8 & Jayawijaya & 3 & 26 & 19 & 5 \\
\hline 9 & Kerom & 5 & 14 & 25 & 9 \\
\hline 10 & Lani Jaya & 1 & 16 & 16 & 20 \\
\hline 11 & Memberamo Raya & 2 & 15 & 23 & 13 \\
\hline 12 & Memberamo Tengah & 2 & 11 & 23 & 17 \\
\hline 13 & Mappi & 8 & 19 & 17 & 9 \\
\hline 14 & Merauke & 22 & 21 & 10 & 0 \\
\hline 15 & Mimika & 32 & 14 & 7 & 0 \\
\hline 16 & Nabire & 13 & 17 & 23 & 0 \\
\hline 17 & Ndunga & 1 & 13 & 24 & 15 \\
\hline 18 & Paniai & 2 & 18 & 26 & 7 \\
\hline 19 & Pegunungan Bintang & 3 & 12 & 22 & 16 \\
\hline 20 & Puncak Jaya & 4 & 12 & 22 & 15 \\
\hline 21 & Puncak & 2 & 14 & 17 & 20 \\
\hline 22 & Sarmi & 4 & 14 & 29 & 6 \\
\hline 23 & Supriori & 2 & 11 & 32 & 8 \\
\hline 24 & Tolikara & 3 & 14 & 23 & 13 \\
\hline 25 & Waropen & 3 & 16 & 27 & 7 \\
\hline 26 & Yahokimo & 3 & 11 & 18 & 21 \\
\hline 27 & Yalimo & 1 & 7 & 19 & 26 \\
\hline 28 & Yapen & 2 & 16 & 21 & 14 \\
\hline 29 & Kota Jayapura & 37 & 14 & 2 & 0 \\
\hline & & & & & \\
\hline & & 27 & \\
\hline & & 3 & 24 \\
\hline
\end{tabular}

TABLE II. THE RESUlTS OF ASSESSMENT OF LEADING SECTORS THROUGH QUESTIONNAIRE

\begin{tabular}{|c|c|c|c|c|c|c|c|c|c|c|}
\hline \multirow{2}{*}{ No } & \multirow{2}{*}{ Territory } & \multicolumn{9}{|c|}{ Leading Sector } \\
\hline & & S1 & S2 & S3 & S4 & S5 & S6 & S7 & S8 & S9 \\
\hline 1 & Asmat & 10 & 1 & 6 & 5 & 5 & 7 & 11 & 1 & 7 \\
\hline 2 & Biak & 9 & 3 & 13 & 2 & 0 & 14 & 2 & 3 & 7 \\
\hline 3 & Boven Digul & 13 & 9 & 13 & 2 & 2 & 0 & 12 & 1 & 1 \\
\hline 4 & Deiyai & 16 & 5 & 3 & 3 & 5 & 1 & 9 & 2 & 9 \\
\hline 5 & Dogiyai & 16 & 8 & 3 & 4 & 7 & 1 & 8 & 1 & 5 \\
\hline 6 & Intan Jaya & 17 & 16 & 5 & 1 & 3 & 3 & 6 & 0 & 2 \\
\hline 7 & Kab Jayapura & 3 & 4 & 11 & 2 & 2 & 20 & 1 & 8 & 2 \\
\hline 8 & Jayawijaya & 12 & 16 & 3 & 3 & 0 & 3 & 9 & 1 & 6 \\
\hline 9 & Kerom & 30 & 2 & 2 & 4 & 4 & 1 & 4 & 1 & 5 \\
\hline 10 & Lani Jaya & 15 & 9 & 2 & 2 & 5 & 3 & 9 & 3 & 5 \\
\hline 11 & Memberamo Raya & 17 & 5 & 6 & 6 & 3 & 2 & 8 & 1 & 5 \\
\hline 12 & Memberamo Tengah & 16 & 6 & 7 & 6 & 2 & 0 & 10 & 1 & 5 \\
\hline 13 & Mappi & 19 & 3 & 8 & 1 & 3 & 1 & 11 & 3 & 4 \\
\hline 14 & Merauke & 43 & 0 & 2 & 1 & 2 & 2 & 0 & 3 & 0 \\
\hline 15 & Mimika & 3 & 42 & 1 & 3 & 0 & 0 & 2 & 0 & 2 \\
\hline 16 & Nabire & 17 & 4 & 12 & 5 & 3 & 6 & 1 & 1 & 4 \\
\hline 17 & Ndunga & 9 & 10 & 6 & 4 & 5 & 2 & 8 & 3 & 6 \\
\hline 18 & Paniai & 18 & 8 & 3 & 5 & 5 & 2 & 9 & 1 & 2 \\
\hline 19 & Pegunungan Bintang & 11 & 12 & 4 & 6 & 5 & 3 & 6 & 1 & 5 \\
\hline 20 & Puncak Jaya & 10 & 16 & 4 & 2 & 5 & 4 & 7 & 1 & 4 \\
\hline 21 & Puncak & 15 & 10 & 3 & 2 & 5 & 3 & 10 & 1 & 4 \\
\hline 22 & Sarmi & 21 & 2 & 9 & 3 & 4 & 4 & 4 & 2 & 4 \\
\hline 23 & Supriori & 14 & 5 & 7 & 3 & 2 & 4 & 10 & 1 & 7 \\
\hline 24 & Tolikara & 16 & 5 & 9 & 3 & 3 & 1 & 10 & 1 & 5 \\
\hline 25 & Waropen & 12 & 5 & 7 & 5 & 3 & 3 & 13 & 1 & 4 \\
\hline 26 & Yahokimo & 15 & 12 & 6 & 2 & 3 & 2 & 7 & 0 & 6 \\
\hline 27 & Yalimo & 16 & 9 & 2 & 4 & 5 & 1 & 8 & 1 & 7 \\
\hline 28 & Yapen & 13 & 6 & 2 & 7 & 5 & 4 & 9 & 1 & 6 \\
\hline 29 & Kota Jayapura & 2 & 4 & 14 & 0 & 3 & 18 & 0 & 10 & 2 \\
\hline
\end{tabular}


The results of the calculation of the percentage of positions as well as conversions into Garrett Value are shown in Table 2 .

Furthermore, the results of the calculation of the percentage of positions are converted into Garrett Value. This Garrett Value then becomes a multiplier component for each result of the assessment carried out by the three decision support elements. The results of the calculation of the percentage of positions as well as conversion into Garret score are shown in Table 3 and Table 4.

In Table 3 and Table 4, it can be seen that the Garret score automatically shows the best ranking sequence based on the percentage position value of each scale. In other cases, the ranking position may differ depending on the value of the questionnaire generated.

TABLE III. The VALUE OF CONVERSION OF THE POSITION AND GARRET SCORE OF PRIORITIZED AREAS

\begin{tabular}{|l|l|l|}
\hline Ranking Scale of & Percentage & Garret score \\
Prioritized Areas & Position & \\
\hline 1 & 12,5 & 73 \\
\hline 2 & 37,5 & 57 \\
\hline 3 & 62,5 & 44 \\
\hline 4 & 87,5 & 28 \\
\hline
\end{tabular}

TABLE IV. The VAlue of CONVERsion of the Position AND GarRet SCORE OF LEADING SECTORS

\begin{tabular}{|l|l|l|}
\hline $\begin{array}{l}\text { Ranking Scale of Leading } \\
\text { Sectors }\end{array}$ & $\begin{array}{l}\text { Percentage } \\
\text { Position }\end{array}$ & Garret score \\
\hline S1 & 5.56 & 81 \\
\hline S2 & 16.67 & 69 \\
\hline S3 & 27.78 & 62 \\
\hline S4 & 38.89 & 56 \\
\hline S5 & 50.00 & 50 \\
\hline S6 & 61.11 & 44 \\
\hline S7 & 72.22 & 38 \\
\hline S8 & 83.33 & 31 \\
\hline S9 & 94.44 & 19 \\
\hline
\end{tabular}

TABLE V. THE AVERAGE GARRET SCORE AND FINAL RANK OF PRIORITIZED AREAS

\begin{tabular}{|l|l|l|l|}
\hline Territory & $\begin{array}{l}\text { Total Garret } \\
\text { Score }\end{array}$ & Average Score & Ranking \\
\hline Kab Jayapura & 3.6 & 67,92 & 1 \\
\hline Kota Jayapura & 3.587 & 67,68 & 2 \\
\hline Mimika & 3.442 & 64,94 & 3 \\
\hline Merauke & 3.243 & 61,19 & 4 \\
\hline Nabire & 2.93 & 55,28 & 5 \\
\hline Biak & 2.814 & 53,09 & 6 \\
\hline Boven Digul & 2.768 & 52,23 & 7 \\
\hline Jayawijaya & 2.677 & 50,51 & 8 \\
\hline Mappi & 2.667 & 50,32 & 9 \\
\hline Sarmi & 2.534 & 47,81 & 10 \\
\hline Kerom & 2.515 & 47,45 & 11 \\
\hline Waropen & 2.515 & 47,45 & 11 \\
\hline Paniai & 2.512 & 47,40 & 13 \\
\hline Intan Jaya & 2.458 & 46,38 & 14 \\
\hline Supriori & 2.405 & 45,38 & 15 \\
\hline Tolikara & 2.393 & 45,15 & 16 \\
\hline Memberamo Raya & 2.377 & 44,85 & 17 \\
\hline Yapen & 2.374 & 44,79 & 18 \\
\hline Asmat & 2.373 & 44,77 & 19 \\
\hline Puncak Jaya & 2.364 & 44,60 & 20 \\
\hline Pegunungan Bintang & 2.319 & 43,75 & 21 \\
\hline Dogiyai & 2.303 & 43,45 & 22 \\
\hline Ndunga & 2.29 & 43,21 & 23 \\
\hline Memberamo Tengah & 2.261 & 42,66 & 24 \\
\hline Puncak & 2.252 & 42,49 & 25 \\
\hline Lani Jaya & 2.249 & 42,43 & 26 \\
\hline Yahokimo & 2.226 & 42,00 & 27 \\
\hline Deiyai & 2.174 & 41,02 & 28 \\
\hline Yalimo & 2.036 & 38,42 & 29 \\
\hline & & & \\
\hline
\end{tabular}

TABLE VI. The Average GarRet Score AND Final RanK OF LEAding SECTORS

\begin{tabular}{|l|l|l|l|}
\hline Leading Sectors & $\begin{array}{l}\text { Total } \\
\text { Garre } \\
\text { t } \\
\text { Score }\end{array}$ & $\begin{array}{l}\text { Averag } \\
\text { e Score }\end{array}$ & $\begin{array}{l}\text { Rankin } \\
\text { g }\end{array}$ \\
\hline S1=Agriculture & 34,668 & 1,195 & 1 \\
\hline S2=Mining & 16,353 & 564 & 2 \\
\hline S3=Industry and Processing & 9,989 & 344 & 3 \\
\hline S7=Transportation and Communication & 7,752 & 267 & 4 \\
\hline S4=Electricity, Gas, and Water Utility & 5,376 & 185 & 5 \\
\hline S6=Trade, Hotels, and Restaurants & 5,060 & 174 & 6 \\
\hline S5=Construction & 4,950 & 171 & 7 \\
\hline S9=Services & 2,489 & 86 & 8 \\
\hline $\begin{array}{l}\text { S8=Financial, Rental, and Business } \\
\text { Services }\end{array}$ & 1,674 & 58 & 9 \\
\hline
\end{tabular}


The next step was to calculate the total Garrett Score by multiplying each value given by the decision maker on the results of the questionnaire (Table 1 and Table 2) by Garrett Value (Table 3 and Table 4), and were then summed up. This treatment applies to the calculation for each region. Then, the average Garret score was calculated by dividing the total Garrett Score in each region by the number of regions being ranked. The final result of Garrett score calculation is region ranking based on the highest average Garrett value. Table 5 shows the average results of Garret score as well as the ranking of the prioritized area, while Table 6 shows the average results of Garret score as well as the ranking for the regional leading sectors.

The results of the Garret ranking showed that Jayapura Regency is in the strongest position to become a prioritized area in the Papua Province. Followed by four other regions; Kab Jayapura, Kota Jayapura, Mimika, Merauke and Nabire. Whereas, getting sorted from ten regions, the other five regions are Biak, Boven Digul, Jayawijaya, Mappi and Sarmi.

The results of leading sectors ranking showed that the Agriculture is the strongest sector to be the leading sector of Regional development in Papua Province. Followed by Mining, Transportation and Communication, and Industry and Processing.

The results of the Garret ranking of prioritized areas and regional leading sectors were then analyzed for correlation of the results of the both ranking. Based on the spearman correlation calculation, it was found that the correlation coefficient is 0.807 with a standard error value of 0.11 . This shows that the results of the ranking carried out on both showed a very strong correlation.

\section{CONCLUSION}

Based on the results of the analysis, it can be seen that there is a very strong correlation between the ranking of the prioritized areas and the leading sectors using the Garrett method. This is indicated by the spearman correlation coefficient which is close to +1 of 0.807 . The results of Garret ranking on 29 regencies/municipalities in Papua Province show that there are five main areas that can be used as prioritized areas, namely Jayapura Regency, Jayapura Municipality, Mimika, Merauke and Nabire. While the regional leading sectors are Agriculture, Mining, and Industry and Processing. Thus, Garret ranking can be used for alternative ranking technique especially for group decision support model that combines the results of ranking with other approaches.

\section{ACKNOWLEDGMENT}

The authors would like to thank the anonymous reviewers for their comments and suggestions that helped to improve the quality and presentation of this paper. This research is supported by Ministry of Research, Technology and Higher Education in the research scheme Doctoral dissertation in 2018.

\section{REFERENCES}

[1] Direktorat Pengembangan Kawasan Khusus dan Tertinggal, Priority Area-Based Regional Economic Development: Building a Model for
Management and Development of Related Program Linkages, Paper of Deputy for Regional Autonomy and Regional Development of BAPPENAS, Government of the Republic of Indonesia, access at July, 03,2018, available at https://www.bappenas.go.id/ files/4513/5080/2311/10pengembangan-ekonomi-daerah-berbasis kawasan-abilitas-membangun-model-pengelol-dan-pengembanganketerkaitanprogram_20081123002641_9.pdf, in Bahasa

[2] Pemerintah Propinsi Kalimantan Utara, Priority Area, access at July, 11, 2018, available at http://simtaru.kaltaraprov.go.id/web/ktr/ kawasanandalan, in Bahasa

[3] Yuda, D.K., and Navitas, P., "Economic Development Direction for Lamongan Regency Based on Leading Sectors (Case Study: Agriculture Sector)," Jurnal Teknik Pomits, Vol.3, No. 2, 2014, pp. C.136 - C.141, in Bahasa

[4] Nazipawati, "Application of Static Models and Dynamic Location Quotients and Shift-Share in Regional Economic Planning: A Case Study of Ogan Komering Ulu District, South Sumatra Province," Jurnal Eko-Regional, Vol. 2 No. 2, 2007, pp. 81 - 86, in Bahasa

[5] Mohanasundaram, P., “ Marketing Probles Faced by Betel Leaf Cultivators," International Journal of Advanced Research, Volume 3, Issue 5, 2015, pp. 1447-1451

[6] Oyelaran, O.A., Tudunwada, Y.Y., Abidoye, J.K., Sanusi, O.M., “A Study on Impact of Work Stress among Mat Factory Workers in Kano Nigeria in," Iranian Journal of Health, Safety \& Environment, Vol.4, No.2, 2015, pp.746-751

[7] Jins, J.P., Radhakrishnan, R., "A Study of Work Stress and Coping Strategies among Tile Factory Workers in Calicut District in Kerala," International Journal of Scientific and Research Publications, Volume 4, Issue 4, 2014, pp. 1 - 9

[8] Suryawanshi, A., and Maharshi, S., "Talent management: Success Mantra for Small and Medium sized Enterprises," Industrial Engineering Letters, Vol.3, No.11, 2013.

[9] Manoharan, R., Selvakumar, K.N., and Pandian, S.S., "Constraints in Milk Production Faced by The Farmers in Pondicherry Union Territority,” Indian J. Anim. Res, Vol. 37, No. 1, 2003, pp. 68 - 70

[10] Nirmala, B. and Suhasini, K., " Armer's experience with hybrid rice technology: A case study of Khunti district of Jharkhand State of India," African Journal of Agricultural Research, Vol. 8, No. 29, 2013, pp. $3973-3975$

[11] Rohit, J., Dubey, S.K., Singh, P., Singh, B.K., and Kumbhare, N.V., "An Assessment of Constraints Faced by the Farmers in Peri-Urban Vegetable Cultivation," International Journal of Current Microbiology and Applied Sciences, Vol. 6, No. 10, 2017, pp. 2245 - 2251

[12] Balaganesh, G., Gautam, Y., Anoop, M., and Singh, H.P., “An Empirical Analysis On Resource Use Efficiency And Constraints In Adoption Of Precision Farming In Banana In Theni District - Tamil Nadu, “Journal Economic Affairs, Vol. 61, No. 3, 2016, pp. 375-380

[13] Vishnuvarthani, S., and Selvaraj, A., "Factors Influencing the Passengers to Select Train Travel: A Study in Salem Division of Southern Railway," International Journal of Scientific and Research Publications, Volume 2, Issue 10, 2012, pp. 1 - 7

[14] Christy, R.J., "Garrett's Ranking Analysis of Various Clinical Bovine Mastitis Control Constraints in Villupuram District of Tamil Nadu," IOSR Journal of Agriculture and Veterinary Science (IOSR-JAVS), Vol. 7, No. 4, 2014, pp. $62-64$

[15] Mbarek, R., Tmar, M., Hattab, H., and Boughanem, M., "A Re-Ranking Method Based on Irrelevant Documents in Ad-Hoc Retrieval," 5th Symposium on Languages, Applications and Technologies (SLATE'16), 2016, pp. 2:1 - 2:10

[16] Jagannatha, A.N., Chen, J., and Yu, H., "Mining and Ranking Biomedical Synonym Candidates from Wikipedia, " Proceedings of the Sixth International Workshop on Health Text Mining and Information Analysis (Louhi), 2015, pp 142-151

[17] Sjafrizal, Ekonomi Regional, Teori dan Aplikasi. Cetakan Pertama. Padang, Baduose Media 2014, In bahasa

[18] Rigopoulus, G., "A Group Decision Support System for Collaborative Decisions Within Business Intelligence Context," American Journal of Information Science and Computer Engineering, Vol. 1, No. 2, 2015, pp. 84-93 
[19] Rayed, C.A., "Developing an Expertise Interaction Meta- Model for Group Decision Support System (GDSS)," Computer Science and Information Technology, Vol. 1, No. 2, 2013, pp. 105-110

[20] Group Support Systems: Tools for HR Yao, J., Wang, J., Xing, R., and Lu, J., "Decision Making," Proceedings of the Third European Academic Workshop on electronic Human Resource Management, Bamberg, Germany, CEUR-WS.org, ISSN 1613-0073, Vol. 570, online: CEUR-WS.org/Vol-570/, 2010, pp. 400-409.

[21] Zhao, X., Chen, Y., Ku, M., Rich, E., Deegan, M., and Luna-Reyes, L.F., "Group Decision Support Systems for Emergency Management and Resilience: CoastalProtectSIM, “ Proceedings of the 50th Hawaii International Conference on System Sciences | 2017, pp. 2489 - 2497

[22] Istudor, I., and Duta, L., "Web-Based Group Decision Support System: an Economic Application, “ Informatica Economică , Vol. 14, No. 1/2010, 2010, pp. $191-200$

[23] Dhanavandan, S., "Application Of Garrett Ranking Technique: Practical Approach," International Journal of Library and Information Studies, Vol. 6, No. 3, 2016, pp. $135-140$. 